\title{
PENGARUH PEMBERIAN BROKOLI KUKUS (BRASSICA OLERACEA) TERHADAP KADAR GLUKOSA DARAH PUASA WANITA PREDIABETES
}

\author{
Nirmaya Esthi Wulandari, Yekti Wirawanni*) \\ Program Studi Ilmu Gizi Fakultas Kedokteran Universitas Diponegoro \\ Jl.Dr.Sutomo No.18, Semarang, Telp (024) 8453708, Email : gizifk@undip.ac.id
}

\begin{abstract}
Background : Pre-diabetes is a state when the blood glucose level are between normal and high (diabetes) range. Diet modification is considered to prevent diabetes. Broccoli is a vegetable which able to lowered blood glucose level. The aim of this study is to analyze the effects of steamed broccoli administration on blood glucose level of prediabetes women.

Methods : This is a pre-experimental study using one group pre and post test design. Subjects on this study were 11 overweight and obese pre-diabetes women whose blood glucose level were ranged from 100 to $125 \mathrm{mg} / \mathrm{dl}$. Each subject received steamed broccoli as much as 140 grams for four weeks. Fasting blood glucose level were measured one day prior and one day after intervention phase using laboratory diagnostic tools. During intervention phase, subject's food intakes were recorded using 24-h recall method. All datas collected were analyzed using Shapiro Wilk and paired t test.

Result : After four weeks intervention, the fasting blood glucose level were significantly decreased $(p=0.001)$, as much as $11.73 \mathrm{mg} / \mathrm{dl}(10.88 \%)$

Conclusion : Administration of steamed broccoli is able to decreases fasting blood glucose significantly.

Keyword : steamed broccoli; fasting blood glucose; pre-diabetes
\end{abstract}

\section{ABSTRAK}

LatarBelakang : Prediabetes merupakan kondisi dimana kadar glukosa darah seseorang berada di antara kadar normal dan diabetes. Cara pencegahan untuk menurunkan risiko diabetes melitus adalah melalui pengaturan diet. Brokoli merupakan salah satu sayuran yang dihubungkan dengan penurunan kadar glukosa darah. Penelitian ini bertujuan untuk membuktikan pengaruh pemberian brokoli kukus terhadap kadar glukosa darah pada wanita prediabetes.

Metode : Jenis penelitian adalah pra eksperimen dengan rancangan one group pre test-post test design. Subjek adalah 11 wanita prediabetes dengan status gizi overweight dan obesitas serta kadar glukosa darah puasa antara 100-125 mg/dl. Tiap sampel diberi brokoli kukus sebanyak 140 gr selama 4 minggu. Kadar glukosa darah puasa diukur satu hari sebelum dan satu hari sesudah intervensi melalui hasil pemeriksaan laboratorium. Selama intervensi, asupan makan subjek diukur dengan metode recall $3 \times 24$ jam. Data yang diperoleh dianalisis menggunakan Shapiro Wilk dan paired t-test.

Hasil : Setelah intervensi selama 4 minggu terjadi penurunan kadar glukosa darah puasa yang signifikan (p=0,001) yaitu sebanyak 11,73 $\mathrm{mg} / \mathrm{dl}(10,88 \%)$.

Kesimpulan : Pemberian brokoli kukus selama 4 minggu dapat menurunkan kadar glukosa darah puasa secara signifikan.

Kata kunci : brokoli kukus; glukosa darah puasa; prediabetes

\section{PENDAHULUAN}

Diabetes Melitus (DM), khususnya DM tipe 2 memiliki angka prevalensi yang semakin tinggi setiap tahunnya. Riset Kesehatan Dasar (RISKESDAS) tahun 2013, menunjukkan prevalensi pre-diabetes di Indonesia yakni mencapai $10,2 \%$ dan penyakit diabetes melitus menduduki ranking ke-2 penyebab kematian yaitu sebesar $14,7 \% .{ }^{1}$ Menurut WHO pasien diabetes di Indonesia mengalami kenaikan dari 8,4 juta jiwa pada tahun 2000 dan akan menjadi sekitar 21,3 juta jiwa pada tahun 2030. Tanpa upaya pencegahan dan program pengendalian yang efektif prevalensi tersebut akan terus meningkat. ${ }^{2}$
Prediabetes adalah kondisi kadar glukosa darah di atas normal tetapi masih di bawah kadar glukosa darah untuk diabetes. ${ }^{3}$ Diagnosis prediabetes ditegakkan bila didapatkan kadar glukosa darah puasa 100-125 mg/dl (Glukosa Puasa Terganggu $=$ GPT), atau 2 jam paska beban glukosa 140-199 mg/dl (Toleransi Glukosa Terganggu $=\mathrm{TGT})$, atau keduanya $($ Homeostatis Glukosa Terganggu $=$ HGT $)^{2}{ }^{2}$

Prediabetes di Indonesia sebagian besar dialami oleh wanita yaitu sebanyak $61,6 \%$ dan 25,3\% pada usia 38-47 tahun. ${ }^{3}$ Faktor risiko terjadinya prediabetes antara lain adalah usia. Berdasarkan data WHO didapatkan bahwa setelah 
mencapai usia 30 tahun, kadar glukosa darah akan naik $1-2 \mathrm{mg} \%$ per tahun pada saat puasa dan akan naik sebesar 5,6-13 $\mathrm{mg} \%$ per tahun pada 2 jam setelah makan. ${ }^{4}$

Brokoli (Brassica oleracea) adalah bunga dari sayuran tanaman sejenis kubis-kubisan. Brokoli memiliki potensi untuk mencegah beberapa penyakit seperti kanker, kardiovaskular, dan diabetes melitus karena mengandung senyawa antioksidan, antikarsiogenik, sulforafan dan serat. Brokoli merupakan salah satu tanaman yang mengandung berbagai macam antioksidan seperti sulforafan, vitamin A dan vitamin C. ${ }^{5}$ Kandungan vitamin $C$ yang cukup tinggi yaitu sebesar $115 \mathrm{mg}$ setiap 100 gram. ${ }^{6}$ Vitamin $C$ berperan sebagai antioksidan primer yang dapat menurunkan resiko stres oksidatif di dalam tubuh. ${ }^{7,8}$

Senyawa lain yang berkaitan dengan penurunan kadar glukosa darah adalah sulforafan. Sulforafan mempunyai peranan sebagai antioksidan yang mengaktifkan aktivitas Nrf2 (Nuclear factor E2-related factor-2). Peningkatan aktivitas Nrf2 dapat menurunkan resistensi insulin, menurunkan perpindahan insuline-sensitive glucose transporter (GLUT-4) dan gangguan metabolisme glukosa. ${ }^{9}$

Brokoli mengandung serat larut air 1,2-1,5g. Kandungan serat terutama serat larut air yang terdapat pada brokoli juga dapat membantu mengontrol kadar glukosa dalam darah. ${ }^{10}$ Serat pangan mampu menyerap air dan mengikat glukosa, sehingga mengurangi ketersediaan glukosa. Diet cukup serat juga mengakibatkan daya cerna karbohidrat berkurang. Keadaan tersebut mampu meredam kenaikan glukosa darah dan menjadikannya tetap terkontrol. ${ }^{11,12}$

Pada penelitian sebelumnya dilakukan penelitian mengenai pemberian jus brokoli pada tikus selama 2 minggu dengan dosis $2,52 \mathrm{gr} / \mathrm{kgBB}$ menghasilkan penurunan yang signifikan pada glukosa darah yaitu sebanyak $42 \%$. $^{7}$ Penelitian lain mengatakan bahwa pemberian BSP (Broccoli Sprout Powder) pada manusia dengan dosis 10 gram selama 4 minggu dapat menurunkan 19,3\% kadar glukosa darah puasa. ${ }^{13}$ Penelitian mengenai pengaruh pemberian jus brokoli dan suplemen brokoli dapat menurunkan kadar glukosa darah, namun penelitian mengenai pemberian brokoli yang dikukus belum pernah dilakukan pada manusia. Hal tersebut mendorong peneliti untuk melakukan penelitian tentang pengaruh pemberian brokoli kukus terhadap kadar glukosa darah pada wanita prediabetes.

\section{METODE}

Penelitian ini merupakan penelitian pra eksperimen dengan rancangan pre test - post test design yang menggunakan manusia sebagai subjek penelitian. Variabel terikat (dependent) dalam penelitian ini adalah kadar glukosa darah. Variabel bebas (independent) adalah pemberian brokoli kukus dengan dosis 140 gram.

Ethical Clearance adalah bentuk persetujuan bahwa secara etik penelitian ini dapat dilakukan pada manusia. Oleh karena penelitian ini bersifat eksperimental yaitu memberikan intervensi khusus pada kelompok perlakuan, sehingga penelitian ini mendapat persetujuan dari Komite Etik, Fakultas Kedokteran Universitas Diponegoro. Pengambilan data sampel termasuk pemeriksaan darah dilakukan setelah mendapat persetujuan dari subjek dengan mengisi informed consent. Keterangan tentang untung dan ruginya mengikuti penelitian, serta efek samping dari intervensi dijelaskan kepada subjek oleh peneliti. Semua data dari penelitian ini hanya dipakai untuk keperluan ilmiah dan kode maupun identitas subjek sangat dirahasiakan untuk umum.

Subjek penelitian merupakan guru wanita di SMPN 2 Patebon Kendal. Sebanyak 33,3\% (18 orang) guru dan karyawan di SMPN 2 Patebon status gizinya overweight dan 5,5\% (3 orang) tergolong obesitas. Oleh karena itu, penelitian dilakukan pada guru dan karyawan di SMPN 2 Patebon.

Kriteria inklusi penelitian ini adalah memiliki kadar glukosa darah puasa 100-125 $\mathrm{mg} / \mathrm{dl}$, memiliki Indeks Massa Tubuh (IMT) $\geq 23,0$ $\mathrm{kg} / \mathrm{m}^{2}$, tidak sedang mengonsumsi obat penurun glukosa darah selama penelitian, dan tidak dalam keadaan sakit atau dalam perawatan dokter.

Perhitungan subjek penelitian menggunakan rumus uji hipotesis terhadap rerata populasi dependen dan dibutuhkan sebanyak minimal 11 subjek. Penentuan subjek penelitian menggunakan metode consecutive sampling. Sebanyak 27 orang bersedia diambil darahnya untuk proses skrining awal dan diperoleh sebanyak 13 orang yang memenuhi kriteria inklusi. Pengambilan darah dilakukan oleh petugas laboratorium dari Laboratorium Sarana Medika Kendal. Subjek sebanyak 13 orang yang memenuhi kriteria inklusi diberikan 140 gram brokoli kukus selama 4 minggu, namun terdapat 2 orang subjek yang mengundurkan diri. Pemberian brokoli diberikan pada subjek dalam bentuk brokoli kukus. Brokoli yang digunakan adalah brokoli varietas green king yang dikukus selama 5 menit dengan suhu $90^{\circ} \mathrm{C}$. 
Asupan makan sehari-hari pada subjek tidak dikontrol. Pencatatan makan dilakukan sebelum dan selama intervensi dengan metode food recall 24 jam. asupan makan subjek dianalisis menggunakan program nutrisurvey.

Untuk menguji kenormalan data menggunakan Shapiro-Wilk. Perbedaan kadar glukosa darah sebelum dan sesudah intervensi menggunakan paired t-test karena data berdistribusi normal.

\section{HASIL PENELITIAN}

Karakteristik Subjek

Karakteristik subjek yang terdiri dari gambaran umur, status gizi, aktivitas fisik dan kadar glukosa awal digunakan untuk mendeskripsikan subjek penelitian secara jelas dan sistematis. Karakteristik subjek penelitian disajikan dalam tabel 1 .

Tabel 1. Karakteristik Awal Subjek Penelitian

\begin{tabular}{|c|c|c|c|}
\hline \multirow{2}{*}{ Variabel } & \multicolumn{3}{|c|}{$\begin{array}{c}\text { Sampel } \\
(n=11)\end{array}$} \\
\hline & Mean \pm SD & $\mathrm{n}$ & $\%$ \\
\hline \multicolumn{4}{|l|}{ Umur } \\
\hline $36-45$ & \multirow{2}{*}{$45,55 \pm 4,61$} & 5 & $45,45 \%$ \\
\hline $46-55$ & & 6 & $54,54 \%$ \\
\hline \multicolumn{4}{|l|}{ Status Gizi } \\
\hline Normal $(18,5-22,9$ kg/m²) & \multirow{3}{*}{$27,14 \pm 5,97$} & 1 & $9,09 \%$ \\
\hline Overweight $\left(23-24,9 \mathrm{~kg} / \mathrm{m}^{2}\right)$ & & 5 & $45,45 \%$ \\
\hline Obesitas $\left(>25 \mathrm{~kg} / \mathrm{m}^{2}\right)$ & & 5 & $45,45 \%$ \\
\hline \multicolumn{4}{|l|}{ Aktifitas Fisik } \\
\hline Ringan & \multirow[t]{2}{*}{-} & 8 & $72,72 \%$ \\
\hline Sedang & & 3 & $27,27 \%$ \\
\hline GDP awal & $107,82 \pm 3,99$ & & \\
\hline
\end{tabular}

Tabel 1 menunjukkan sebagian besar subjek dalam penelitian ini berada pada kelompok umur 46-55 tahun $(54,54 \%)$, sebagian diantaranya memiliki kategori status gizi obesitas $(45,45 \%)$ dan overweight $(45,45 \%)$, tingkat aktivitas fisik sebagian besar tergolong ringan $(72,72 \%)$.

\section{Asupan Makan Sebelum dan Selama Intervensi}

Faktor yang mempengaruhi kadar glukosa adalah asupan energi, protein, karbohidrat, lemak, serat, dan gula. Perbedaan rerata asupan makan 3 hari sebelum dan selama intervensi ditunjukkan pada tabel 2 .

Tabel 2 . Rerata asupan makan sebelum dan selama intervensi

\begin{tabular}{|c|c|c|c|c|c|c|}
\hline $\begin{array}{c}\text { Asupan } \\
\text { makan }\end{array}$ & $\begin{array}{l}\text { Sebelum } \\
\text { intervensi }\end{array}$ & $\begin{array}{c}\% \\
\text { Kecukupan }\end{array}$ & $\begin{array}{c}\text { Selama } \\
\text { intervensi }\end{array}$ & $\begin{array}{c}\% \\
\text { Kecukupan }\end{array}$ & $\Delta$ Asupan & $\mathbf{p}$ \\
\hline & Mean \pm SD & & Mean \pm SD & & Mean \pm SD & \\
\hline Energi & $1592.6 \pm 134.39$ & $101,8 \%$ & $1513.1 \pm 178.52$ & $96,2 \%$ & $-79.72 \pm 127.65$ & $0.076^{*}$ \\
\hline Karbohidrat & $198,35 \pm 40.39$ & $89,3 \%$ & $183,39 \pm 38.65$ & $82,6 \%$ & $-14.81 \pm 13.42$ & $0.005^{*}$ \\
\hline Lemak & $51.24 \pm 24.98$ & $123,4 \%$ & $52.16 \pm 29.85$ & $126 \%$ & $0.92 \pm 15.23$ & $0.575^{*}$ \\
\hline Protein & $61.96 \pm 8.76$ & $78,93 \%$ & $60.39 \pm 10.70$ & $76,98 \%$ & $-1.49 \pm 2.84$ & $0.125^{*}$ \\
\hline Serat & $10.20 \pm 3.82$ & $40,8 \%$ & $9.63 \pm 3.58$ & $38,5 \%$ & $-0.67 \pm 10.46$ & $0.362^{*}$ \\
\hline Gula & $51.88 \pm 8.60$ & $104,5 \%$ & $50.21 \pm 9.66$ & $101,5 \%$ & $-1.67 \pm 3.28$ & $0.012^{*}$ \\
\hline
\end{tabular}

* paired t-test

Tabel 2 menunjukkan bahwa rerata asupan energi, lemak, protein, karbohidrat, serat dan gula pada sebelum intervensi lebih tinggi daripada selama intervensi. Secara statistik tingkat konsumsi energi, protein, lemak, dan serat tidak menunjukkan perbedaan yang bermakna $(p>0.05)$, kecuali untuk tingkat konsumsi karbohidrat dan gula terdapat perbedaan yang bermakna $(\mathrm{p}<0.05)$ antara sebelum dan selama intervensi.

\section{Kepatuhan Subjek dalam Mengkonsumsi Brokoli Kukus}

Selama penelitian, subjek mendapat intervensi berupa brokoli kukus sebanyak 140 gram selama 4 minggu. Namun pada penelitian ini terdapat 2 orang subjek yang mengundurkan diri 
pada minggu ke-3 intervensi. Berdasarkan kepatuhan subjek dalam mengkonsumsi brokoli kukus diperoleh hasil sebanyak 9 subjek tidak menyisakan brokoli kukus dan terdapat 1 orang subjek yang menyisakan brokoli kukus sebanyak $25 \%$ selama 1 hari dan 50\% selama 5 hari sehingga asupan brokolinya hanya $89,95 \%$ serta 1 orang subjek yang menyisakan brokoli kukus sebanyak $25 \%$ selama 2 hari dan $50 \%$ selama 3 hari sehingga asupan brokolinya hanya $91,89 \%$.

Pengaruh konsumsi brokoli kukus terhadap kadar glukosa darah puasa

Tabel 3. Pengaruh konsumsi brokoli kukus terhadap kadar glukosa darah puasa

\begin{tabular}{ccccc}
\hline \multirow{2}{*}{ Variabel } & Awal & Akhir & $\Delta$ GDP & p \\
\cline { 2 - 5 } & Mean \pm SD & Mean \pm SD & Mean \pm SD & \\
$*$ Kadar GDP $(\mathrm{mg} / \mathrm{dl})$ & $107.82 \pm 3.99$ & $96.09 \pm 6.73$ & $11.73 \pm 8.73$ & $0.001 *$ \\
\hline \multirow{2}{*}{ Kaired } & & & &
\end{tabular}

Tabel 3 menunjukkan adanya penurunan kadar glukosa darah puasa (GDP) setelah pemberian brokoli kukus selama 4 minggu. Rerata penurunan GDP adalah sebesar 11,73 $\mathrm{mg} / \mathrm{dl}$ $(10,88 \%)$. Berdasarkan analisis statistik didapatkan bahwa terdapat perubahan rerata glukosa darah puasa setelah diberi intervensi $(\mathrm{p}<0,05)$. Artinya ada pengaruh konsumsi brokoli kukus terhadap kadar glukosa darah puasa.

\section{PEMBAHASAN}

Pengambilan subjek pada penelitian ini adalah wanita karena wanita memiliki risiko mengalami prediabetes lebih tinggi dibanding pria. Wanita mempunyai risiko mengalami gangguan toleransi glukosa lebih tinggi dibanding pria. Hal ini disebabkan karena wanita memiliki komposisi lemak tubuh lebih besar. Komposisi lemak yang tinggi menyebabkan wanita cenderung lebih mudah gemuk yang berkaitan dengan risiko gangguan toleransi glukosa. ${ }^{14}$ Selain itu tingkat aktivitas fisik wanita lebih rendah dibanding pria. Kurangnya aktivitas fisik pada penderita prediabetes menyebabkan zat makanan yang masuk ke dalam tubuh tidak diubah menjadi energi melainkan ditimbun di dalam tubuh sebagai lemak dan gula. ${ }^{15}$

Rata rata umur subjek pada penelitian ini adalah 45 tahun dengan rata rata kadar glukosa darah 107,82 $\mathrm{mg} / \mathrm{dl}$ yang sudah tergolong prediabetes. Kadar glukosa darah dipengaruhi oleh usia dan jenis kelamin. Kadar glukosa darah semakin meningkat dimulai dari usia $>30$ tahun. Hal ini terjadi karena pada usia $>30$ tahun mulai terjadi proses penuaan. Proses penuaan mengakibatkan terjadinya penurunan produksi insulin dan peningkatan resistensi insulin. ${ }^{16}$

Sampel minimal penelitian ini adalah 11 orang. Pada awalnya jumlah sampel yang diperoleh adalah 13 orang, tetapi 2 orang subjek mengundurkan diri di minggu ke-3 intervensi dan salah satunya berstatus gizi normal. Subjek pada penelitian ini memiliki kategori status gizi obesitas $(45,45 \%)$, kategori overweight $(45,45 \%)$, dan normal $(9,09 \%)$. Obesitas merupakan faktor risiko terjadinya diabetes melitus dimana sekitar $80-90 \%$ penderita mengalami obesitas. Kelebihan berat badan akan beresiko terkena hiperglikemi. Lemak yang menumpuk dalam tubuh membuat sel $\beta$ kurang bekerja secara aktif untuk menyerap hormon insulin. ${ }^{14,17}$ Obesitas sentral yang dialami sebagian besar subjek dapat mengakibatkan resistensi insulin. Resistensi insulin pada penderita obesitas sentral terjadi karena lemak viseral berperan dalam serangkaian perubahan sekresi adipokin yang menghasilkan sejumlah sitokin proinflamasi seperti Tumor Necrosis Factors (TNF- $\alpha$ ), interleukin-1 (IL-1) dan interleukin-6 (IL-6) yang dapat mengganggu aktifitas normal insulin dalam sel lemak dan sel otot serta toksisitas pada sel- $\beta$ pankreas. ${ }^{18,19}$

Brokoli merupakan sayuran yang biasa dikonsumsi dan mudah diperoleh. Kandungan sulforafan yang terdapat di dalamnya merupakan senyawa antioksidan dan antidiabetik yang mempunyai pengaruh dalam menurunkan kadar glukosa darah. ${ }^{20}$ Antioksidan yang terdapat dalam brokoli mampu menstabilkan radikal bebas yang menyebabkan kerusakan pada sel $\beta$ pankreas dan menghambat kerja insulin. ${ }^{721}$ Stres oksidatif pada penderita diabetes akan menghambat pengambilan glukosa di sel otot dan sel lemak serta penurunan sekresi insulin oleh sel- $\beta$ di pankreas. ${ }^{21}$ Penurunan hormon insulin mengakibatkan glukosa darah di dalam tubuh akan meningkat. Selain itu, senyawa sulforafan merupakan aktivator Nrf2 (Nuclear factor E2-related factor-2) yang dapat menurunkan resistensi insulin dan mampu melindungi kerusakan sel $\beta$ pankreas pada penderita diabetes melalui penurunan pembentukan molekul ROS (Reactive Oxygen Species) sebesar $73 \%$ akibat kondisi hiperglikemi. ${ }^{9}$ 
Brokoli yang diberikan dalam bentuk brokoli kukus. Pengukusan merupakan proses pengolahan yang paling baik karena tidak banyak menyebabkan perubahan terhadap kandungan zat gizi seperti kadar vitamin $\mathrm{C}$ dan antioksidan. ${ }^{22}$ Selain itu pemasakan dengan cara dikukus menunjukkan kandungan antioksidan yang lebih tinggi. ${ }^{21}$ Pengukusan dapat meningkatkan aktivitas antioksidan brokoli sebesar tiga kali lipat dibandingkan brokoli mentah. Aktivitas antioksidan brokoli mentah adalah 1,1 mmol Trolox/100 gram, sedangkan brokoli kukus memiliki aktivitas antioksidan sebesar 3,51 mmol Trolox/100 gram. Pengukusan menyebabkan penghancuran dinding sel dan pelepasan antioksidan dari kompleks protein yang terdapat dalam matriks tanaman sehingga konsentrasi antioksidan pada brokoli kukus lebih tinggi dibandingkan brokoli mentah..$^{23,24}$

Dosis brokoli yang diberikan mengacu pada penelitian sebelumnya yang dilakukan pada tikus yaitu sebesar 2,52 gram dan apabila dikonversikan pada manusia dikalikan dengan tabel konversi dari tikus ke manusia (56) menjadi 140 gram. $^{7}$ Kandungan dalam 140 gram brokoli kukus adalah sulforafan $\pm 15,67 \mathrm{~g}$, kalori 43,68 kal, dan serat $4,68 \mathrm{~g} \cdot{ }^{13}$

Asupan subjek selama penelitian diukur dengan metode food recall 24 jam sebelum dan selama intervensi dengan tujuan untuk mengetahui apakah terdapat perbedaan asupan sebelum dan selama intervensi dan untuk dibandingkan dengan kebutuhan energi yang dibutuhkan berdasarkan perhitungan. Kebutuhan energi basal masingmasing subjek dihitung menggunakan rumus Harris Benedict dan dikoreksi dengan aktivitas fisik yang tergolong ringan.

Rerata asupan energi, lemak, protein, karbohidrat, serat, dan gula pada sebelum intervensi lebih tinggi daripada selama intervensi. Penurunan asupan energi, lemak, protein, karbohidrat, serat, dan gula dikarenakan subjek mengurangi porsi makan. Hal tersebut mengakibatkan kalori yang diasup menjadi berkurang sehingga dapat membantu mengendalikan kadar glukosa darah. Akan tetapi secara statistik tidak terdapat perbedaan asupan energi, protein, lemak, dan serat $(p>0,05)$. Sedangkan untuk asupan karbohidrat dan gula terdapat perbedaan yang bermakna $(p<0,05)$.

Tingkat asupan energi subjek pada sebelum dan saat intervensi tergolong baik sesuai dengan kebutuhan. Rata-rata asupan energi antara sebelum dan selama intervensi mengalami penurunan sebesar 79,72 kkal. Penurunan energi tersebut dikarenakan subjek mengurangi porsi makan terutama pada sumber karbohidrat seperti nasi dan makanan atau minuman manis. Hal tersebut dapat mempengaruhi adanya penurunan kadar GDP setelah intervensi. Total energi mempengaruhi kadar glukosa darah karena semakin tinggi energi memacu resistensi insulin sehingga apabila energi yang diasup berkurang maka resistensi insulin dapat dikendalikan dan tidak terjadi peningkatan kadar GDP. ${ }^{16}$ Namun tidak terdapat perbedaan yang bermakna antara asupan energi sebelum dan selama intervensi $(p=0,076)$. Asupan lemak pada subjek sebelum intervensi melebihi kebutuhan rata-rata sebesar $123 \%$, kemudian pada saat intervensi mengalami peningkatan sebesar $126 \%$ dari total kebutuhan. Tingginya proporsi lemak juga dihubungkan dengan menurunnya sensitivitas insulin. ${ }^{17}$ Namun tidak terdapat perbedaan yang bermakna antara asupan lemak sebelum dan saat intervensi $(\mathrm{p}=0,575)$. Tingkat asupan protein subjek sebelum dan saat intervensi rata-rata tergolong cukup dari total kebutuhan. Asupan protein sebelum dan selama intervensi mengalami penurunan sebesar 1,49 gram. Namun tidak terdapat perbedaan yang bermakna antara asupan protein antara sebelum dan selama intervensi $(\mathrm{p}=0,125)$. Asupan serat pada subjek baik sebelum maupun saat intervensi belum memenuhi kebutuhan yang direkomendasikan karena hanya terpenuhi sebanyak 38-40\%. American Dietetic Association (ADA) merekomendasikan kecukupan serat harian yaitu 20-35 g/hari atau berdasarkan Dietary Reference Intake (DRI) setara dengan 14 g/1000 kkal. ${ }^{25}$ Serat dapat membantu mengontrol kadar glukosa dalam darah. ${ }^{10}$ Serat mampu menyerap air dan mengikat glukosa sehingga mengurangi ketersediaan glukosa. Sedangkan di usus halus, serat meningkatkan kekentalan isi usus yang mengakibatkan penurunan enzim $\alpha$-amilase dan memperlambat penyerapan glukosa sehingga dapat mengurangi kenaikan kadar glukosa darah. ${ }^{15,26}$ Namun tidak terdapat perbedaan yang bermakna antara asupan serat sebelum dan saat intervensi $(\mathrm{p}=0,362)$.

Rata-rata tingkat asupan karbohidrat pada subjek antara sebelum dan selama intervensi tergolong cukup dari total kebutuhan. Terdapat penurunan asupan karbohidrat antara sebelum dan selama intervensi sebesar 14,81 gram. Adanya penurunan tersebut disebabkan karena subjek mengurangi asupan nasi dan makanan atau minuman yang manis. Hasil uji statistik menunjukkan bahwa terdapat perbedaan yang bermakna antara asupan karbohidrat pada sebelum 
dan selama intervensi $(p=0,005)$, sehingga penurunan asupan karbohidrat dapat menjadi faktor yang dapat mempengaruhi turunnya kadar GDP pada subjek. Asupan karbohidrat subjek yang sebagian besar bersumber dari nasi dan gula. Nasi merupakan sumber karbohidrat utama yang bersifat hiperglikemi karena memiliki Indeks Glikemik (IG) yang tinggi sehingga cepat menaikkan kadar glukosa. ${ }^{27}$.Asupan gula subjek rata-rata melebihi standar kebutuhan. Menurut Peraturan Menteri Kesehatan Republik Indonesia no 30/2013, anjuran konsumsi gula adalah maksimal 50 gram per hari. Berdasarkan data asupan makan subjek, diketahui bahwa terdapat 7 orang subjek yang mengkonsumsi gula melebihi kebutuhan rata-rata sebesar 104,5\%. Asupan gula subjek sebagian besar menurun antara sebelum dan selama intervensi, terdapat 8 subjek yang asupan gulanya menurun dan 3 subjek yang asupan gulanya meningkat yaitu sebesar 1,6 gram, 4,9 gram, dan 3 gram. Sebanyak 2 subjek dari 8 subjek yang asupan gulanya turun tidak menghabiskan brokoli kukus $100 \%$ dan terjadi peningkatan kadar GDP setelah pemberian intervensi, sehingga dapat dimungkinkan peningkatan kadar GDP pada subjek dikarenakan 2 orang subjek tersebut hanya mengkonsumsi brokoli kukus sebanyak 89,95\% dan $91,89 \%$ saja. Subjek yang tidak menyisakan brokoli kukus seluruhnya mengalami penurunan kadar GDP dengan nilai rata-rata $14,88 \mathrm{mg} / \mathrm{dl}$, sedangkan 1 subjek yang menyisakan 11,97\% brokoli kukus mengalami peningkatan kadar GDP sebesar $3 \mathrm{mg} / \mathrm{dl}$ dan 1 orang subjek yang menyisakan brokoli $13,29 \%$ mengalami peningkatan kadar GDP sebesar $2 \mathrm{mg} / \mathrm{dl}$.

\section{SIMPULAN}

Terdapat penurunan glukosa darah puasa (GDP) yang signifikan $(\mathrm{p}<0,05)$ sebesar 11,73 $\mathrm{mg} / \mathrm{dl} \quad(10,88 \%)$ setelah dilakukan pemberian intervensi berupa brokoli kukus sebanyak 140 gram/hari selama 4 minggu.

\section{SARAN}

Melanjutkan penelitian dengan menggunakan kelompok kontrol dan melakukan uji laboratorium untuk mengetahui kadar kandungan sulforafan yang dikonsumsi pada

\section{DAFTAR PUSTAKA}

1. Hasil Riset Kesehatan Dasar (RISKESDAS). 2013. Prevalensi Diabetes.

2. Meddy Setiawan. Pre-diabetes dan Peran HBA1C dalam Skrining dan Diagnosis awal Diabetes
Melitus. Jurnal Saintika Medika. 2011. Vol. 7 No.14.

3. Pradana Soewondo, Laurentius A. Pramono. Prevalence, characteristic, and predictors of prediabetes in Indonesia. Med J Ind. 2013. Vol. 20, No. 4.

4. Indra Kurniawan. Diabetes Melitus Tipe 2 pada Usia Lanjut. Majalah Kedokteran Indonesia, 2010. Volume : 60, No. 12

5. Muh. Aniar Hari Swasono. Optimasi Pengolahan Kaldu Ayam dan Brokoli dalam Bentuk Instan dan Analisa Biaya Produksi [Tesis]. Program Pascasarjana Universitas Brawijaya; 2008.

6. Anderson JW. Plant Fiber in Foods. $2^{\text {nd }}$ ed. HCF Nutrition Research Foundation Inc 2004;81.

7. Dwi Yuliani. Pengaruh Pemberian Jus Brokoli (Brassica oleracea L. var. Italia) terhadap Penurunan Kadar Glukosa Darah Tikus Putih (Rattus norvegicus strain wistar) Model Diabetes Mellitus [Skripsi]. Fakultas Kedokteran Hewan Institut Pertanian Bogor, 2009.

8. Nurdiana. Pengaruh Jus Brokoli (Brassica oleracea L. var. Italia) terhadap Penurunan Kadar Low Density Lipoprotein (LDL) Darah pada Tikus Putih (Rattus norvegicus) Model Diabetes Mellitus yang Diinduksi STZ. [Skripsi]. Fakultas Kedokteran Hewan Institut Pertanian Bogor, 2009.

9. Jialin Xu, Supriya R. Kulkarni, Ajay C. Donepudi, Vijay R.. Enhanced Nrf2 Activity Worsens Insulin Resistance, Impairs Lipid Accumulation in Adipose Tissue, and Increases Hepatic Steatosis in Leptin-Deficient Mice. J.Xu and Associates. 2012. Vol. 61

10. Dietetians of Canada. 2008. Food Sources of Soluble Fiber.

11. Agus Santoso. Serat Pangan (Dietary Fiber) dan Manfaatnya bagi Kesehatan. Magistra No. 75 Th. XXIII 2011. ISSN 0215-9511

12. American Diabetes Association. Standards of Medical Care in Diabetes-2007. Diabetes Care 2007; 30: 4-41

13. Zahra Bahadoran, Parvin Mirmiran, Farhad Hosseinpanah, Asadolah Rajab, Fereidoun Aziz. Broccoli Sprouts Powder Could Improve Serum Triglyceride And Oxidized LDL/LDL-Cholesterol Ratio In Type 2 Diabetic Patients. Diabetes Research and Clinical Practice, 2012. 348 - 354

14. Whitney E, Rolfes SR, Pinna K. Nutrition dan Diabetes Mellitus. Dalam : Understanding Normal and Clinical Nutrition $7^{\text {th }}$ edition. Belmont : Wadsworth; 2002. Hal 790-816

15. Meyes PA. Glukoneogenesis dan Pengontrolan Kadar Glukosa Darah. Dalam : Murray RK, Granner DK, Mayes PA, Rodwell VW. Biokimia Harper $25^{\text {th }}$ edition. Jakarta : EGC; 2003. Hal. 178216

16. Perkumpulan Endokrinoligi Indonesia. Konsensus Pengelolaan dan Pencegahan Diabetes Melitus Tipe 2 di Indonesia. Jakarta : PB. PERKENI; 2006. Hal 3-14, 30-31. 
17. Schteingart DE. Pankreas : Metabolisme Glukosa dan Diabetes Melitus. Dalam : Price SA, Wilson LM. Patofisiologi Konsep Klinis Proses-Proses Penyakit. $6^{\text {th }}$ edition. Jakarta : 2003. Hal 1259-74.

18. Mlinar B, Marc J, Janez A, Pfeifer M. Molecular mechanism of insulin resistance anda associated disease. 2007;20-35

19. Haffner SM. Abdominal obesity, insulin resistance and cardiovascular risk in prediabetes and type 2 diabetes. Eur Heart J Supplements. 2006; B20-25

20. Muhammad Anwar Waqar, Yasir Mahmood. Antiplatelet, anti-hypercholestrolemic and antioxidant effects of ethanolic of brassica oleracea in high fat diet provided rats. World Applied Sciences Journal 8 (1):107-112,2010.

21. Andrea Mahn, Alejandro Reyes. An overview of health-promoting compounds of broccoli (Brassica oleracea var. italica) and the effect of processing. Food Science and Technology International. 2012 18: 503

22. Anna Pods, edek. A review : Natural antioxidants and antioxidant capacity of Brassica vegetables. Institute of Technical Biochemistry, Faculty of Biotechnology and Food Science, Technical University of $\mathrm{Lo}^{\prime} \mathrm{dz} \mathrm{z}^{\prime}, 90-924 \quad \mathrm{Lo}^{\prime} \mathrm{dz}$, Stefanowskiego 4/10, Poland.2005

23. Monika Kartamiharja, Ieva B Akbar, Salli Fitrianti. Perbedaan Pengaruh Pemberian Brokoli (Brassica Oleracea) Organik dan Brokoli Non-Organik Kukus terhadap Kadar Malondialdehid Plasma pada Tikus Jantan Galur Wistar yang Diinduksi Aloksan Monohidrat. Jurnal Medika Planta 2011. Vol. 1 No. 3

24. Totušek J., Tř́íska J., Lefnerová D., Strohalm J.,VrchotováN., Zendulka O., et al. Contents of sulforaphane and total isothiocyanates, antimutagenic activity, and inhibition of clastogenicity in pulp juices from cruciferous plants. 2011. Czech J. Food Sci., 29: 548-556.

25. Dreher ML. Dietary Fiber Overview. Indiana : Mead Johnson Nutritionals/Bristol-Myers Squibb Company, Evansville. 2001

26. Franz MJ. Medical Nutririon Theraphy for Diabetes Mellitus and Hypoglycemia of Nondiabetic Origin. Dalam : Mahan LK, Stump ES. Krause's Food, Nutrition and Diet Theraphy $1^{\text {th }}$ edition. Pensylvania : Saunders; 2004. Hal 792-837

27. Beras untuk Penderita Diabetes. Warta Penelitian dan Pengembangan Pertanian Vol. 31, No. 2, 2009 